\title{
Guppy (Poecilia) Poeciliidae fish naturally infected with Lernaea cyprinacea parasites (Linnaeus 1758) in KSA
}

\section{Original Article}

\author{
Mahi A Ghobashy', Hewaydah E AbouShafeey², Azza A Taeleb ${ }^{3}$ \\ Departments of Zoology, Faculty of Science, Suez Canal ${ }^{1}$, Tanta ${ }^{2}$, and Zagazig ${ }^{3}$ Universities, \\ Egypt
}

\begin{abstract}
Background: The ornamental fish guppy (Poecilia reticulata) is a small colorful tropical cyprinid teleost fish. Lernaea cyprinacea (Anchor worm) are worldwide, crustacean copepod parasites that cause disease and mortality in several fish species of cultured or natural populations, especially wild-caught and pond-raised species of Poecilia. This study may be considered as a novel report from Kingdom of Saudi Arabia (KSA).

Objective: The present study is an investigation of Lernaea isolates infecting apparently healthy Poecilia reticulate from KSA.

Material and Methods: Guppy fish (Poecilia reticulata) were purchased two weeks prior to experiments. They were examined for parasitic infection and allowed to breed in the laboratory. They were observed for 15 days for appearance of infection by Lernaea spp. larva and adult parasites. The copepod specimens were removed by forceps, from different parts of the infected fish. Specimens were fixed in $70 \%$ alcohol, cleared in $90 \%$ lactic acid, mounted, and microscopically examined to identify the morphological features of L. cyprinacea.

Results: After 15 days, L. cyprinacea were detected in the ventral, anal and caudal fins of several P. reticulata. Intense focal inflammation and hemorrhage was easily observed at the attachment site, which appeared red and ulcerated. Total prevalence of infection was $68.1 \%$ (32/47). The prevalence of infection in females $(29 / 38 ; 76.3 \%)$ was greater than in males $(3 / 9 ; 33.3 \%)$.
\end{abstract}

Conclusion: $P$. reticulata may be considered as a newly recorded host of $L$. cyprinacea from KSA.

Keywords: copepoda, guppy, Lernaea cyprinacea, Poecilia reticulata.

Received: 24 September, 2018, Accepted: 19 November, 2018 .

Corresponding Author: Hewaydah E AbouShafeey, Tel. : 01112351723, E-mail: hewaydah@yahoo.com

Print ISSN: 1687-7942, Online ISSN: 2090-2646, Vol. 11, No. 3, December, 2018.

\section{INTRODUCTION}

Lernaea species are crustacean, copepod parasites that can infect and cause disease and mortality in many types of freshwater fishes, especially wildcaught and pond-raised species (both cultured and natural populations). L. cyprinacea (commonly known as Anchor worm), a parasitic cyclopoid copepod, is found worldwide; mostly in cyprinids. Several species ( $\sim 110$ species) of lernaeids (Lernaea and Lernaea-like parasites) have been described and L. cyprinacea, is one of the more common among them $^{(1)}$

The economic importance of lernaeids has increased in several parts of the world as the cause of one of numerous diseases among most farmed fish species; especially fingerlings, leading to death even with only a small number of infested lernaeids $s^{(2-4)}$. Death of fish and/or associated damage is relative to the rate of parasitic infestation ${ }^{(5)}$.

Infestations occur more commonly in stagnant or slow-moving water bodies. L. cyprinacea, exhibits little host specificity and has been reported previously from a variety of freshwater fishes, frogs, frog tadpoles, and adult and larval salamanders. Although infestations are common in cyprinids, including koi, goldfish, and other related carp, numerous other freshwater species are susceptible ${ }^{(6-8)}$. Lernaea species have nine stages in their life cycle, including three free-living naupliar stages, five copepodid stages and one adult stage. During development, the different stages live on and off the fish. After mating, the male copepod dies and the female bores into fish tissue, eventually using a large anchor anterior end "head" to permanently embed into the skin and muscle of the fish ${ }^{(9,10)}$. This direct life cycle can take from 18 to 25 days to complete and only a fish (or an amphibian) is necessary for Lernaea spp. to develop from egg to mature adult. Common sites of Lernaea infestation include the skin, fins, gills, and oral cavity. Large numbers of lernaeids in their copepodid stages can kill small fish by damaging their gills and interfering with their breathing. Fish can survive with Lernaea infestation, but chronic conditions frequently result in poor growth and debilitation; the fish become more susceptible to secondary infection by bacteria and fungus which ultimately kills them ${ }^{(11-14)}$. 
Guppy ( $P$. reticulata) is a small and colorful tropical ornamental teleost. It is a member of the family Poeciliidae ${ }^{(15)}$ that undergo internal fertilization $^{(16)}$. Guppies, whose natural habitat is in northeast South America, were introduced to many countries and are now found all over the world. They are highly adaptable and thrive in many different environmental and ecological conditions ${ }^{(15)}$. Male guppies, which are smaller than females, have ornamental caudal and dorsal fins, while females are duller in color.

In several tropical countries they were used for biological control of mosquito larvae, the vectors of infectious malaria disease ${ }^{(17,18)}$ and filariasis ${ }^{(19-21)}$. The guppy became a model for biological studies because of its short generation interval, ease of breeding in laboratories, and the availability of many different strains $^{(22-24)}$.

Although L. cyprinacea parasites infect a wide range of both fish culture and natural populations fishes, few species of Lernaea were described especially those infecting ornamental fishes that still require further research. This study investigates Lernaea infections in guppy $(P$ reticulata), the ornamental, small and colorful fish, in a sample from KSA.

\section{MATERIAL AND METHODS}

The present study was carried out in the laboratory of Zoological Research, Biology Department, Faculty of Science, Taif University, KSA. From a local breeder in El-Taif, KSA, 47 fish (38 females and 9 males) guppy ( $P$. reticulata) specimens (only colored, active, healthy and sexually mature males and females) were purchased (Figure 1) and transferred to the aquaria two weeks prior to the examination. They were allowed to breed in the laboratory. The fish were daily examined for external copepod parasitic infection. All aquaria were provided with thermostats $100 \mathrm{~W}$, thermometers, air pumps, air lines, and gravel cleaner or dip tube (Figure 2). The water in the aquaria was obtained from a header tank containing constantly aerated (dechlorinated) water composed of deionized water mixed with local tap water $(5: 1)$. The tap water was analyzed, and its specifications were as follows: $\mathrm{pH}$ 8.46; total dissolved saline $2.52 \mathrm{ppm}$; conductivity $0.0054 \mathrm{mS} / \mathrm{cm}$. After 15 days, infection with the larvae and adult of copepod parasites was observed. The adult copepod specimens were removed by forceps from different parts of the infected fish; skin and pectoral, ventral and dorsal fins. Specimens fixed in $70 \%$ alcohol were cleared in $90 \%$ lacto phenol and mounted in dibutylphthalate polystyrene xylene
(DPX). The mounted specimens were examined and photographed using a Zeiss light microscope ${ }^{(25)}$. The morphological identification of the $L$. cyprinacea specimens was performed according to Robinson ${ }^{(26)}$.

Animal use followed a protocol approved and authorized by Institutional Animal Care and Use Committee (IACUC).

Statistical analysis: The copepod preference for attachment sites on the host was recorded. Infestation parameters, prevalence and intensity were calculated by QP3.0 (Quantitative Parasitology 3.0). This parasitology software provides statistically correct medians to analyze the highly aggregated (right-skewed) frequency distributions exhibited by parasites. QP3.0 describes parasitic infections within a sample of hosts and compares parasitic infections across different samples of hosts. Mann-Whitny test was applied to test the significance difference in parasite number at $\leq 0.05$ using SPSS.

\section{RESULTS}

Apparently healthy guppy fish ( $P$. reticulata), small colorful tropical ornamental teleosts, were purchased and examined for ectoparasites (Figures 1-3). They were kept under observation for signs of infection related to change in color and active movement. After an observation period of 15 days, natural infection was gradually noted in 32/47 fishes (29 females and 3 males) with a prevalence of $68.1 \%$. By examination of fixed specimens, the body of adult $L$. cyprinacea female appeared long and tubular with an anchor on its anterior end and paired egg sacs on the posterior end. The anterior anchor was embedded into the fish's body while the posterior end, with its egg sacs, protruded out into the water (Figures 4-7). Adult females had a body length of 10.3-11.10 mm; body width of $0.36-0.40 \mathrm{~mm}$ to $0.50-0.56 \mathrm{~mm}$ from anterior to posterior respectively; length of horn ranged from 1.38 to $1.43 \mathrm{~mm}$; egg sac length and width were 3.3 $3.9 .0 \mathrm{~mm}$ and $0.50-0.54 \mathrm{~mm}$, respectively.

Adult females were anchored to host fins, feeding on the epithelial cells and mucus of the fish, characteristically raising blisters on the surface of the fins. The female parasites were found burrowed deep into the tissues with the anterior anchor embedded into the fish's body. Intense focal inflammation and hemorrhage were easily observed at the attachment site, making the area appear red and ulcerated. The scales of infected fish fell off.

Fish with severe infection (more than 5 parasites per fish) on their body surface showed dull colors and sluggish movement. Newly hatched nauplii observed 


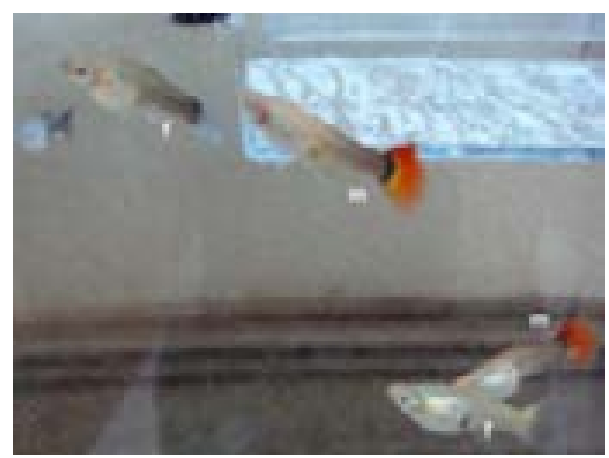

Fig. 1. Male and female Guppy.

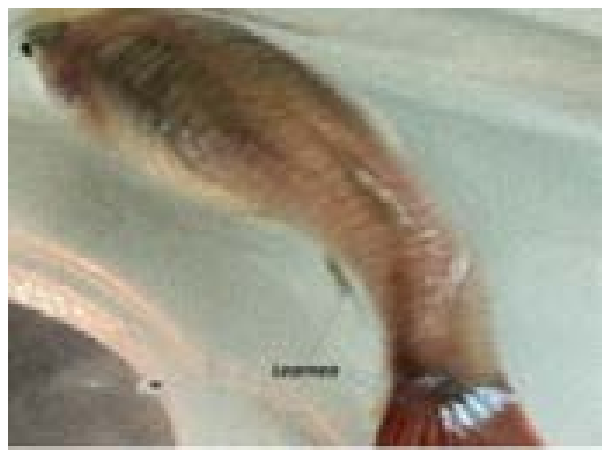

Fig. 3. Female Guppy carrying Learnea on the anal fin.

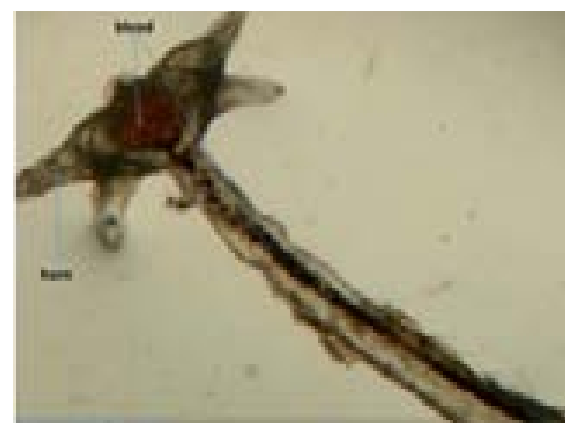

Fig. 5. An adult female of Lernaea anterior part of the body full of blood (X40).

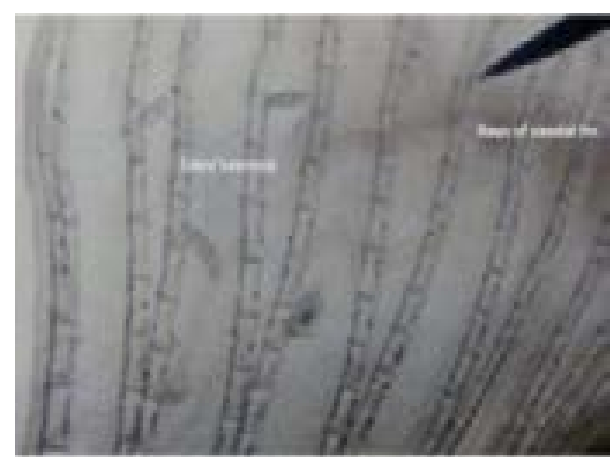

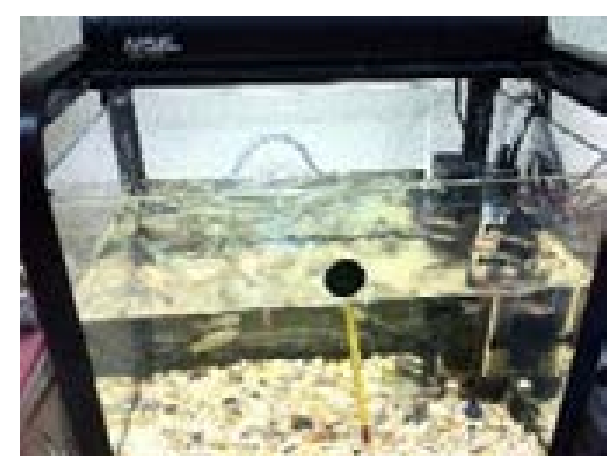

Fig. 2. The aquarium with the optimum condition.

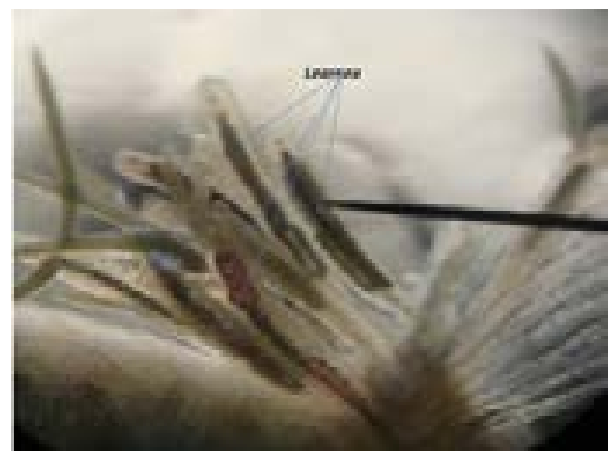

Fig. 4. Number of Learnea heads embedded in the fish tissue of ventral fin (X10).

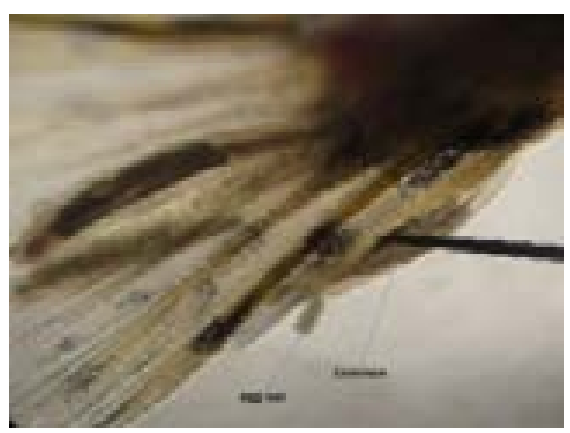

Fig. 6. Caudal fin of Guppy with attached L. cyprinacea (X40).

Fig. 7. Larval Lernaea attached to the rays of the caudal fin $(X 40)$. 
on the caudal fin of the infected fish (not parasitic), develop through naupliar stages (Figure 6), after which they became parasitic, and attached to the host. The copepod stages were found on the gills but were not permanently embedded in the tissue.
The infection was high in the female guppy reaching $76.3 \%(29 / 38)$ and decreased to $33.3 \%$ in male guppy (3/9). Number of parasites was significantly higher in females than males $(P<0.05)$ (Table 1$)$, fixed especially on ventral and anal fins (Table 2 ).

Table 1. Prevalence of infestation, mean abundance and intensity, median $\mathrm{r}$ of the parasites Lernaea cyprinacea in relation to sex.

\begin{tabular}{rcccccc}
\hline \multicolumn{1}{c}{ Sex } & Range* $^{*}$ & Prevalence & Mean abundance & Median & Mean intensity \\
\hline Female & $1-12$ & $76.7 \%$ & 0.97 & 4 & $4.33 \pm 0.50$ \\
Male & $2-5$ & $33.3 \%$ & 0.33 & 2 & $3.0 \pm 0.58$ \\
\hline \hline
\end{tabular}

* Range of parasites number on each infested host.

Table 2. Parasite sites and attachment-preference on Guppy (Poecilia reticulate).

\begin{tabular}{lcccccc}
\hline \hline Sex & Skin (n) & Pectoral fin (n) & Ventral fins (n) & Dorsal fins (n) & Anal fins (n) & Caudal fins (n) \\
\hline Female & 6 & 7 & 12 & 2 & 8 \\
Male & 2 & 0 & 5 & 0 & 0 \\
\hline \hline
\end{tabular}

n: Number of copepod specimens

\section{DISCUSSION}

The ornamental guppy $(P$. reticulata) fish, though apparently healthy at time of purchase proved to be naturally parasitized by ovigerous female L. cyprinacea on their skin and fins. Other records in the literature show that Lernaea infestations are particularly common in fish of the carp family (Cyprinidae), including koi, goldfish, and other related carp, as well as other numerous susceptible freshwater species. About 64 species of fish were recorded as host for L. cyprinacea $^{[27]}$. The same researchers stressed the importance of careful examination of all aquatic species for anchor worms to determine parasite infestation by L. cyprinacea. In 2017, Baliga et al., ${ }^{[28]}$ isolated copepods that had different anchor shapes, from freshwater fishes including $P$. reticulata; and proved that they were genetically identical belonging to the same L. cyprinacea species.

The present study is the first record of infection by L. cyprinacea (68.1\%) in this sample of guppy fish examined from KSA. Although L. cyprinacea seems to have a random choice for attachment on the body host, it was shown that the parasites were fixed especially on the fins and $\operatorname{skin}^{[29]}$. The same observations were previously reported in many other literatures ${ }^{[30-34]}$. This may be because fins offer greater protection against currents and tissues and the base of the fins are more easily penetrated ${ }^{[3,35,36]}$. In our study there is enough evidence to conclude that there is a significant difference $(P<0.05)$ in number of parasites between infected males and females (Table 1). The study revealed that the parasites have preference for fixation in descending order for: ventral, anal, and pectoral fins; skin and caudal fins came last. Females were significantly more susceptible to infection than males and even the parasite load of females doubled that of the males. It was reported that severe focal damage to affected tissues caused by parasites, increases the risk of infection by bacterial and fungal pathogens present in the environment. In flowing rivers and streams, anchor worm infections are usually limited to a single parasite per fish host, causing little damage, but in closed environments severe infestations often result ${ }^{[29,37]}$. Suggested differences in susceptibility of fish species to the parasite could be due to differences in ecological, behavioral and physiological mechanisms, and morphological variations. Some fish species such as those that are without scales might produce hormones or secrete mucous which renders them unacceptable to the copepod or makes them immune ${ }^{[10,38]}$

The tightly packed structure and arrangement of scales in some fish species might not allow for easy implantation of the parasite's anchor. This also explains the higher parasite intensity in smaller and younger fish which are easily accessible to the parasite, or in whom the defense mechanisms are less well developed compared with larger or older fish ${ }^{[34]}$. Parasitic crustaceans harm the fish in several ways: they cause tissue damage due to permanently attached adults, result in stunted growth of fish and retarded or inhibited reproduction. This is probably because of the nutritional drain, though also it may be because of hormonal changes and feeding. Attachment of parasites to fish is frequently associated with anemia of the fish ${ }^{[39]}$. Previous studies ${ }^{[9,14,16,36,40-66]}$ recorded other fish hosts from all over the world susceptible to L. cyprinacea (Table 3).

In conclusion, the parasite in this host was reported in previous studies in other fish species. $P$. reticulata may be considered as a newly recorded host of $L$. cyprinacea in KSA. 
Acknowledgements: Authors are thankful to Prof. Youmn Mobarak and Roaa Kamal for their great help.

Author contribution: MA Ghobashy conceived and designed the research, performed the research, analyzed the data, contributed and shared in writing the paper. AA Taeleb performed the research, contributed in analyzing the data, and revised the results. HE
AbouShafeey contributed and shared in writing the article, revised and prepared the manuscript for publication.

Conflict of interest: There is no conflict of interest.

Financial support and sponsorship: Nil

Table 3. List of L. cyprinacea records on different host species from all over the world.

\begin{tabular}{|c|c|c|}
\hline Host(s) of L. cyprinacea & Country & References \\
\hline $\begin{array}{l}\text { Silurus asotus, Arapaima gigas, Anguilla japonica, Carassius auratus, Carassius } \\
\text { auratus langsdorfii, Carassius auratus subsp., Carassius cuvieri, Ctenopharyngodon } \\
\text { idellus, Cyprinus carpio, Gnathopogon elongatus suwae, Hemibarbus labeo, } \\
\text { Oncorhynchus mykiss, Pseudobagrus tokiensis, Plecoglossus altivelis, Pungitius } \\
\text { pungitius, Lepomis macrochirus, Micropterus salmoides, Pterophyllum scalare, } \\
\text { Chaenogobius macrognathos, Gymnogobius Tridentiger obscurus }\end{array}$ & Japan & {$[9,40]$} \\
\hline Odontesthes bonariensis & Argentina & [14] \\
\hline Lepomis gibbosus, Pseudorasbora parva & Romania & [16] \\
\hline $\begin{array}{l}\text { Labeo altivelis, Oreochromis macrochir, Ctenopharyngodon idella, } \\
\text { Oreochromis mossambicus, Oreochromis placidus, Tilapia rendalli }\end{array}$ & Zimbabwe & [29] \\
\hline $\begin{array}{l}\text { Alburnus alburnus, Barbus lacerta, Capoeta aculeate, Capoeta damascina, Capoeta } \\
\text { aculeate gracilis,Carassius carassius, Chalcalburnus chalcoides, Chalcalburnus } \\
\text { mossulensis, Chondrostoma orientalis, Ctenopharyngodon idella, Cyprinus carpio, } \\
\text { Leuciscus cephalus, Hypophthalmichthys molitrix, Mastacembelus mastacembelus, } \\
\text { Pseudorasbora parva, Aphanius vladykovi, Aristichthys nobilis, Chondrostoma } \\
\text { regium, Gobio sp., Leuciscus persidis, Schizothorax sp. A. stellatus }\end{array}$ & Iran & {$[32,41-44]$} \\
\hline $\begin{array}{l}\text { Barbus graellsii, Barbus haasi, Cyprinus carpio, Leuciscus cephalus, } \\
\text { Chondrostoma toxostoma, Parachondrostoma miegii }\end{array}$ & Spain & {$[35,45]$} \\
\hline $\begin{array}{l}\text { Ctenopharyngodon idella, Catla catla, Labeo rohita, } \\
\text { Hypophthhalmichthys moltrix, Cirrhinus mrigala }\end{array}$ & Pakistan & {$[36,46-48]$} \\
\hline $\begin{array}{l}\text { Carassius carassius, Poecilia latipinna, Chondrostoma nasus, Gambusia affinis, } \\
\text { Pseudophoxinus burduricus, Gambusia holbrooki, Oxynoemacheilus anatolicus }\end{array}$ & Turkey & {$[49-54]$} \\
\hline Carassius auratus, Carp, Clarias lazera, Tilapia sp, Hypophthalmichthys molitrix & Egypt & [55-58] \\
\hline Barbus altianalis, Lates albertianus & Uganda & [59-60] \\
\hline Cyprinus carpio, Carassius carassius, Idus idus, Rutilus rutilus & Britain & [61] \\
\hline Gambussia affinis & Italy & [62] \\
\hline Natropis girardi, Macrhybobsis tetranema & Mexico & [63] \\
\hline Astyanax bimaculatus & Brazil & [64] \\
\hline Barbus barbulus, B.grypus, B. luteus, Cyprinus carpio,Leuciscus Lepidus & Iraq & [65] \\
\hline $\begin{array}{l}\text { Galaxias occidentalis, Edelia vittata , Bostockia porosa, Tandanus bostocki, } \\
\text { Carassius auratus, Gambusia holbrooki, Phalloceros caudimaculatus }\end{array}$ & W. Australia & [66] \\
\hline Poecilia reticulate & KSA & Present stduy \\
\hline
\end{tabular}

\section{REFERENCES}

1. Lester RG, Hayward CJ. Phylum Arthropoda in: Woo PTK. fish diseases and disorders: protozoan and metazoan infections. Wallingford CAB International 2006; 1:466-565.

2. Kabata Z. Parasites and diseases of fish cultured in the Tropics. Taylor and Francis, London 1985: 318 pages.
3. Molnár K. Solving parasite related problems in cultured freshwater fish. Int J Parasitol 1987; 17(2): 319-326.

4. Hemaprasanth KP, Raghavendra A, Singh R, Sridhar $\mathrm{N}$, Raghunath MR. Efficacy of doramectin against natural and experimental infections of Lernaea cyprinacea in carps. Vet Parasitol 2008; 156(3-4): 261-269. 
5. Deborah DI. Overview on the effects of parasites on fish health. United States Geological Survey, Leetown Science Center, National Fish Health Research Laboratory. Proceedings of the $3^{\text {rd }}$ Bilateral Conference between Russia and the United States "Bridging America and Russia with Shared Perspectives on Aquatic Animal Health" 2011; 3 .

6. Hoffman GL. Parasites of North American freshwater fishes. $2^{\text {nd }}$ Ed. Cornell University. Press. New York, 1999; 317 pages.

7. Green DE, Converse KA, Schrader AK. Epizootiology of sixty-four amphibian morbidity and mortality events in the USA, 1996-2001. Ann New York Acad Sc 2002; 969:323-339.

8. Kupferberg SJ, Catenazzi A, Lunde K, Lind AJ, Palen WJ. Parasitic copepod (Lernaea cyprinacea) outbreaks in foothill yellow-legged frog (Rana boylii) linked to unusally warm summers and amphibian malformations in Northern California. Copeia 2009; 3: 529-537.

9. Nagasawa $\mathrm{K}$, Inoue $\mathrm{A}$, Myat $\mathrm{S}$, Umino T. New host records for Lernaea cyprinacea (Copepoda), a parasite of freshwater fishes, with a checklist of the Larnaeidae in Japan (1915-2007). J Grad Sch Biosp Sci, Hiroshima University, 2007; 46:21-33.

10. Barson M, Mulonga A, Nhiwatiwa T. Investigation of a parasitic outbreak of Lernaea cyprinacea Linnaeus (Copepoda) in fish from Zimbabwe. Afri Zool 2008; 43:175-183.

11. Abbas F, Ashraf M, Hafeez-ur-Rehman M, Iqbal KJ, Abbas S, Javid A. Lernaea susceptibility, infestation and its treatment in indigenous major and exotic Chinese carps under polyculture system. Pakistan J Zool 2014; 46(5): 1215-1222.

12. Hossain MM, Ferdoushi J, Rupom AH. Biology of anchor worms (Lernaea cyprinacea). J Entomol Zool Stud 2018; 6(1): 910-917.

13. Hossain MMM, Rahman MZ, Islam MA, Alam ME, Rahman H. Lernaea (Anchor Worm) investigations in Fish. Int J Anim Fish Sci 2013; 1(1) 12-19.

14. Soares IA, Salinas V, Ponti O del, Mancini MA, Luque JL. First molecular data for Lernaea cyprinacea (Copepoda: Cyclopoida) infesting Odontesthes bonariensis, a commercially important freshwater fish in Argentina. Braz J Vet Parasitol, Jaboticabal 2018; 27(1): 105-108.

15. Magurran, AE. Evolutionary Ecology: The Trinidadian Guppy. New York: Oxford University Press 2005.
16. Auer SK. Arendt JD, Chandramouli R, Reznick DN. Juvenile compensatory growth has negative consequences for reproduction in trinidadian guppies (Poecilia reticulata). Ecological Letters 2010; 13(8): 998-1007.

17. Fernando AA, Phang VPE. Culture of the guppy, Poecilia reticulata, in Singapore. Aquaculture 1985; 51: 49-63.

18. Rojas E, Gamboa M, Villalobos S, Cruzado F. Eficacia del control de larvas de vectores de la malaria con peces larvívoros nativos en San Martín, Perú. Revista Peruana de Medicina Experimental Salud Publica 2004; 21(1): 4-50.

19. Dua, V.K., Pandey A.C., Rai S., Dash A.P. Larvivorous activity of Poecilia reticulata against Culex quinquefasciatus larvae in polluted water drain in Hardwar, India. J Am Mosq Control Assoc 2007; 23(4): 481-483.

20. Chandra, G., Bhattacharjee I, Chatterjee SN, Ghosh. A. Mosquito control by larvivorous fish. IJMR 2008; 127(1): 13-27.

21. Kusumawathie AR, Wickremasinghe ND, Wijeyaratne MJS. Costs and effectiveness of application of Poecilia reticulata (guppy) and temephos in anopheline mosquito control in river basins below the major dams of Sri Lanka. Trans Roy Soc Hyg 2008; 102 (7): 705-711.

22. Martyn U, Weigel D, Dreyer C. In vitro culture of embryos of the guppy, Poecilia reticulata. DEV DYNAM 2006; 235: 617-622.

23. Magellan k, Magurran AE. Male choice, sexual coercion and gene flow in guppy populations. J Fish Biol 2007; 71: 1864-1872.

24. Mobarak YM. Mercuric chloride delays growth of guppy (Poecilia reticulata) larvae. J Egypt Ger Soc Zool 2009; 58: 25-41.

25. Bauer O.N. Opredelitel parazitov presnovodnych ryb fauny SSSR.T. 3. (Guide to the parasites of the freshwater fish fauna of the USSR. Parasitic Metazoa). Nauka Leningradskoe Otdelenie, Leningrad 1987; 583.

26. Robinson J, Oldewage AA. Aspects of the morphology of the parasitic copepod Lernaea cyprinacea linnaeus, 1758 . Notes on its distribution in Africa. Crustaceana, 1996; 69(5): 610-626.

27. McAllister CT, Bursey CR, Martin SD. Lernaea cyprinacea (Crustacea: Copepoda: Lernaeidae) anchorworms from two larval aquatic insects (Ephemeroptera: Baetidae; Trichoptera: 
Hydropsychidae) in northeastern Oklahoma. Proc Okla Acad Sci 2011; 91:37-40.

28. Baliga P, Shanker KM, Ballayay A, Ahmed I. Molecular identification of the fish parasite Lernaea. Indian J Fish 2017; 64(2): 76-82.

29. Dalu T, Nhiwatiwa T, Clegg B, Barson M. Impact of Lernaea cyprinacea linnaeus 1758 (Crustacea: Copepoda) almost a decade after an initial parasitic outbreak in fishes of Malilangwe Reservoir, Zimbabwe. KMAE 2012; 406(3): 1-9.

30. Kim JH, Hayward CJ, Joh SJ, Heo GJ. Parasitic infections in live freshwater tropical fishes imported to Korea. Dis Aquat Organ 2002; 52, 169-173.

31. Jalali B, Barzegar M, Nezamabadi H. Parasitic fauna of the spiny eel, Mastacembelus mastacembelus Banks et Solander (Teleostei: Mastacembelidae) in Iran. IJVR, Shiraz University, 2008; 9, 158-161.

32. Barzegar M, Jalali B. Crustacean parasites of fresh and brackish (Caspian Sea) water fishes of Iran. J Agr Sci Technol 2009; 11: 161-171.

33. Stavrescu-Bedivan MM, Popa OP, Popa LO. Infestation of Lernaea cyprinacea (Copepoda: Lernaeidae) in two invasive fish species in Romania, Lepomis gibbosus and Pseudorasbora parva. Knowl Managt Aquatic Ecosyst 2014; 414: 12p1-12p10.

34. Koyun M, Ulupinar M, Mart A. First Record of Lernaea cyprinacea L. 1758 (Copepoda: Cyclopoida) on Cyprinion macrostomus Heckel, 1843 from Eastern Anatolia, Turkey. Biharean Biologist 2015; 9(1):44-46.

35. Gutierrez-Galindo JF, Lacasa-Millan MI. Population dynamics of Lernaea cyprinacea (Crustacea: Copepoda) on four cyprinid species. Dis Aquat Organ 2005; 67(1-2): 111-114.

36. Iqbal Z, Rani I, Pervaiz K. Treatment of lernaeasis in carps with thunder: An organophosphate. Pakistan J Zool 2012; 44(2): 415-420.

37. Demaree Jr, Richard S. Ecology and external morphology of Lernaea cyprinacea. American Midland Naturalist 1967; 78(2): 416-427.

38. John O, Whitaker Jr, Schlueter RA. Occurrence of the crustacean parasite, Lernaea cyprinacea, on fishes from the white rriver at Petersburg, Indiana. Am Midland Naturalist 1975; 93 (2): 446-450.

39. Rameshkumar G, Ravichandran S. New host record, Rastrelliger kanagurta, for Nerocila phaeopleura parasites (Crustacea, Isopoda, Cymothoidae). Middle-East J Sci Res 2010; 5 (1): 54-56.
40. Ogawa, K. Metazoan diseases. infectious and parasitic diseases of fish and shellfish. In: Wakabayashi, H. Muroga, K. (eds), Koseisha Koseikaku 2004; 381-405.

41. Jalali B. Lerneasis in cyprinid cultured fish in Iran. Master Thesis. Godolo University. Hungary 1987; P: 21.

42. Jalali B. Parasites and parasitic diseases of fresh water fishes of Iran. $1^{\text {st }}$ Edition., Fisheries Co. of Iran 1998; P: 564 (In Persian).

43. Pazooki J, Masoumian M. Synopsis of the parasites in Iranian freshwater fishes. Iran J Fish Sci 2012; 11(3): 570-589.

44. Bozorgnia A, Sharifi N, Reza MY, Barzegar M. Acipenser stellatus as a new host record for Lernaea cyprinacea linnaeus, 1758 (Crustacea; Copepoda), a parasites of freshwater fishes in Iran. J Aqua Mar Biol 2018; 7(3):123-125.

45. Sterling JE, Carbonell E, Estellés-Zanón EJ, Chirivella J. Estudio estacional del parasitismo por Lernaea cyprinacea en la madrilla Chondrostoma toxostoma miegii (Pisces: Cyprinidae) en un afluente del río Ebro. Proc $4^{\text {th }}$ Iber Cong Parasitol Santiago de Compostela Spain1992; 90-91.

46. Tasawar Z, Zafar S, Lashari MH, and Hayat CS. The prevalence of lernaeid ectoparasites in grass carp (Ctenopharyngodon idella). Pak Vet J 2009; 29: 95-96.

47. Kanwal N, Siraj Z, Tasawar Z, Mushtaq F, Lashari $\mathrm{MH}$. The Lernaeid parasites of Catla catla. Acta Parasitologica Globalis 2012; 3(2): 16-19.

48. Aslam S, Abbas A, Kalhoro MA, Shoaib A. Anchor worms (lernaeid parasites), Lernaea polymorpha уӥ and Lernaea cyprinacea $L$ (copépode: Lernaeidae) on major carps at different fish farms in Punjab, Pakistan. Sci Int (Lahore) 2016; 28 (1): 295-298.

49. Tekin OS, Kir I. An investigation of parasites of goldfish (Carassius carassius L., 1758) in Kovada Lake. Turkiye Parazitoloji Dergisi 2005; 29(3): 200-203.

50. Koyuncu CE, Donmez AE. The infection of Lernaea cyprinaceae (Linnaeus, 1758) in some of the aquarium fishes (Poecilidae) in Mersin district. Ege Üniversitesi Su Ürünleri Dergisi 2006; 23: 265-267.

51. Kir I. The effects of parasites on the growth of the crucian carp (Carassius carassius L., 1758) inhabiting the Kovada Lake. Turkiye Parazitoloji Dergisi 2007; 31: 162-166. 
52. Innal D, Avenant-Oldewage A. Occurrence of Lernaea cyprinacea on mosquito fish (Gambusia affinis) from Kundu Estuary (Antalya-Turkey). Eur Assoc Fish Path (EAFP) 2012; 32(4): 140-147.

53. Demir S, Karakişi H. Metazoan parasites of Nasa (Chondrostoma nasus L., 1758) from Tahtall Dam Lake (Izmir Province, Turkey). Biharean Biologist 2014; 8(2): 95-97.

54. Innal D, Avenant-Oldewage A, Dogangil B, StavrescuBedivan MM, Ozmen O, Mavruk S. Susceptibility of endemic and non-indigenous fish to Lernaea cyprinacea (Copepoda: Lernaeidae): a case study from Düger Spring Creek (Burdur-Turkey). Bull Eur Ass Fish Pathol 2017; 37(3): 96-105.

55. Faisal M, Easa MS, Shalaby SI, Ibrahim MM Epizootics of Lernaea cyprinacea (Copepoda: Lernaeidae) in imported cyprinids to Egypt. Tropenlanwirt 1988; 89: 131-141.

56. Essa M. Control of lernaeosis in Egypt with special reference to recent strategies. Expert consultation on fish health research in Egypt. Abbassa research center, Abou Hammad Sharkia, Egypt 2003.

57. Amina I. El-Mansy. On the occurrence of adult females of Lernaea species (Crustacea: Copepoda) parasitic on goldfish Carassius auratus (Linnaeus) in some commercial aquaria in Egypt. Egypt J Aquat Biol Fish (EJABF) 2009; 13(1):7-36.

58. Nofal ME, Zaki VH, El-Shebly AA. Implications of heavy infestation of Lernaea cyprinacea (Crustacea: Copepoda) of Silver carp, Hypophthalmichthys molitrix at Manzala area, with trial for control using Trichlorfon. Int J Fish Aqua Stud 2016; 4(6): 314318.

59. Thurston JP. The biology of Lernaea barnimiana (Crustacea, Copepoda) from Lake George, Uganda.
Revue Zoologie et de Botanique Africanes 1969; 80:15-33.

60. Thurston JP. The incidence of monogenea and parasitic crustacea on the gills of fish in Uganda. Revue Zoologie et de Botanique Africanes 1979; 82: 113-130.

61. Fryer G. The parasitic copepod Lernaea cyprinacea L. in Britain. J Nat Hist 1968; 2:531-533.

62. Benedetti I, Mola L, Monari E, Sabatini MA, Marini M, Fratello B. Preliminary findings on the development of the parasitic copepod Lernaea cyprinacea $L$. from cleavage to hatching. Bollettino di Zoologia 1989; 56(1): 7-11.

63. Durham BW, Bonner TH, Wilde GR. Occurrance of Lernaea cyprinacea on Arkansas river shiners and peppered chubs in the Canadian river, New Mexico and Texas, The Southwestern Naturalist 2002; 47: 95-97.

64. Magalhães ALB. First record of lernaeosis in a native fish species from a natural environment in Minas Gerais state, Brazil. Pan-Am J Aquat Sci 2006; 1: 8-10.

65. Al-Margan KSN. Some ectoparasites of the common carp (Cyprinus carpio) with experimental study of the life cycle of the anchor worm (Lernaea cyprinacea) in Ainkawa fish hatchery, Erbil province. M. Sc. Thesis, Sci. Educ. Coll., Univ. Salahaddin 2007; 99 pp.

66. Marina H, Beatty SJ, Morgan DL, Doupe RG Lymbery AJ. An introduced parasite, Lernaea cyprinacea $L$., found on native freshwater fishes in the south west of Western Australia. The J R Soc West Aust 2008; 91: 149-153. 